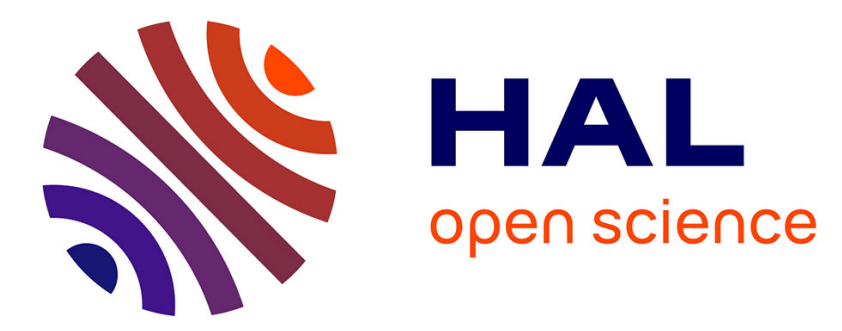

\title{
Between Facts and Interpretations: Three Images of the Balkan Wars of 1912-13
}

\author{
Enika Abazi
}

\section{To cite this version:}

Enika Abazi. Between Facts and Interpretations: Three Images of the Balkan Wars of 1912-13. James Pettifer; Tom Buchanan. War in the Balkans: Conflict and Diplomacy before World War I, I.B.Tauris, pp.203-225, 2016, 978-1-78453-190-4. 10.5040/9780755621729.ch-0010 . halshs-01252639

\section{HAL Id: halshs-01252639 \\ https://shs.hal.science/halshs-01252639}

Submitted on 11 Jan 2016

HAL is a multi-disciplinary open access archive for the deposit and dissemination of scientific research documents, whether they are published or not. The documents may come from teaching and research institutions in France or abroad, or from public or private research centers.
L'archive ouverte pluridisciplinaire HAL, est destinée au dépôt et à la diffusion de documents scientifiques de niveau recherche, publiés ou non, émanant des établissements d'enseignement et de recherche français ou étrangers, des laboratoires publics ou privés. 


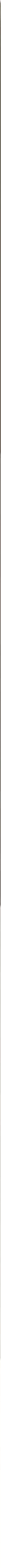


The history of the Balkans incorporates all the major historical themes of the twentieth century - the rise of nationalism, communism and fascism, state-sponsored genocide and urban warfare. Focusing on the century's opening decades, War in the Balkans seeks to shed new light on the Balkan Wars through approaching each regional and ethnic conflict as a separate actor, before placing them in a wider context. Although top-down "Great Powers" historiography is often used to describe the beginnings of World War I, not enough attention has been paid to the events in the region in the years preceding the Archduke Ferdinand's assassination. The Balkan Wars saw the defeat of the Ottoman Empire, the end of the Bulgarian Kingdom (then one of the most powerful military countries in the region), an unprecedented hardening of Serbian nationalism, the swallowing up of Slovenes and Croats in a larger Balkan entity, and thus set in place the pattern of border realignments which would become familiar for much of the twentieth century.

\section{"Always in the shadow of World War I, the Balkan Wars haven't got the attention they deserve in historiography. This fine piece of scholarship assembles the findings of researchers from the region itself and from outside, addressing a variety of intriguing topics. It tells among others of the fight against cholera, of Croat sympathies and help for Serbia, of the role of war correspondents, of the meaning of the wars for the symbolic representation of the region as well as of the mutual perception in the Balkans of the time." Prof. Dr Nada Boškovska, University of Zurich}

\section{James Pettifer was Professor in the Defence Academy of the} United Kingdom from 2002 to 2012, and teaches modern Balkan history at St Cross College, Oxford.

Tom Buchanan is Professor of Modern British and European History at the University of Oxford, where he is Director of Studies in History and Politics at the Department for Continuing Education and a Fellow of Kellogg College. 


\title{
WAR IN THE BALKANS
}

Conflict and Diplomacy before World War I

\author{
Edited by \\ James Pettifer and Tom Buchanan
}




\section{Published in 2016 by \\ I.B. Tauris \& Co. Led \\ London - New York \\ www.ibtauris,com}

Copyright editorial selection (c) 2016 James Petcifer and Tom Buchanan Copyright individual chapters (C) 2016 Enika Abazi, Tom Buchanan, Robert Evans, Bernd J. Fischer, Melina Grizo, Helen Katsiadakis, Jasmina Knezovic, James Petrifer, Christian Promitzer, Sabrina P. Ramet, Biljana Vankovska and Eric Becketc Weaver

The right of James Pecrifer and Tom Buchanan to be identified as the editors of this work has been asserted by the editors in accordance with the Copyright,

Designs and Pacents Act 1988.

All rights reserved. Except for brief quotations in a review, this book, or any part thereof, may not be reproduced, srored in or introduced into a retrieval system, or transmitted, in any form or by any means, electronic, mechanical, photocopying, recording or orherwise, without the prior written permission of the publisher.

References to websites were correct at the time of writing.

International Library of Twentieth Century History 84

ISBN: 9781784531904

eISBN: 9780857739681

A full CIP record for this book is available from the British Library

A full CIP record is available from the Library of Congress

Library of Congress Catalog Card Number: available

Typeset in Garamond Three by OKS Prepress Services, Chennai, India

Printed and bound by CPI Group (UK) Ltd, Croydon, CR0 4YY

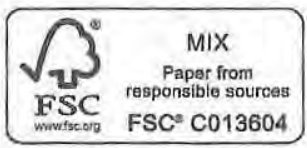




\section{CONTENTS}

Foreword R.J.W. Evans $\quad$ ix

Contributors xiii

\section{Part I The Contested Inheritance}

1. The Balkan Wars after 100 Years 3 Tom Buchanan

2. Realpolitik or Foreign Policy Surrealism: A Reconsideration of the Peace Treaties of Berlin (1878), London (1913), Versailles (1919), and Trianon (1920)

Sabrina P. Ramet

\section{Part II International Dimensions}

3. Yugoslavism in Hungary during the Balkan Wars Eric Beckett Weaver

4. Combating Cholera during the Balkan Wars: The Case of Bulgaria

Christian Promitzer

5. The Balkan Wars and the Creation of Albanian Independence Bernd J. Fischer 
6. History and Memories of the Balkan Wars in the Republic of Macedonia: Debates over the Past

Biljana Vankouska

7. After the Golden Age? - The Journalism of the Balkan Wars

James Pettifer

8. Croatian Nationalism and the Balkan Wars Jasmina Knezovic

Past III The Bitter Inheritance

9. Macedonia - The Crisis After the Paris Peace Conference 183 Melina Grizo

10. Between Facts and Interpretations: Three Images of the Balkan Wars of 1912-13

Enika Abazi

11. The Balkan Wars Experience: Understanding the Enemy

226 Helen Katsiadakis

2. Some Concluding Thoughts James Pettifer

dex 


\title{
CHAPTER 10
}

\section{BETWEEN FACTS AND INTERPRETATIONS: THREE IMAGES OF THE BALKAN WARS OF 1912-13}

\author{
Enika Abazi
}

A century after the Balkan Wars of $1912-13$ there is a widely held opinion that they represent an important moment in the political history of the Balkan states. Images of the Balkan Wars were revived during the brutal dissolution of Yugoslavia in the 1990s. In many of the books, articles and reports written at this time the ghosts of past Balkan wars were paraded uncritically before a watching world. The "spiciest" examples, mainly taken from the Carnegie Report of 1914, reprinted with a new introduction (Kennan 1993), were repeatedly reproduced, especially those concerning ethnic hatred, ethnic cleansing, massacres, violence against women and children, torture of prisoners, deportation of civil populations, destruction of towns and villages, and the plight of refugees. The purpose of invoking the 1912-13 Balkan Wars for a present-day audience was to bridge the two extremes of the twentieth century in order to "better understand the roots of Balkan passions" (Kennan 1993, 13, Kaplan 1993) as if the old Balkan Wars had guaranteed the subsequent tragedy in the 1990s. The very "repetitiveness" of the practices associated with the wars of 1912-13 appeared to reveal legacies that still influenced the ways in 
which politics, behaviour, and affairs of states and people are condueceil in the Balkans.

The Balkan "blight", endlessly produced and reproduced, keeps alin a "Balkanist" discourse, in Maria Todorova's terms $(1997,17=201$ On the one hand, at the beginning of the wars of the 1990s, this discourse legitimised humanitarian and military interventions, and the recognition of seceding republics (Kissinger 1999). On the other it "re-Balkanised Southeast Europe and revived old Western stereorypus about the Balkans and Balkanisation" (Simić 2013, 114), thus hardening ideas about the Balkan barbarian "other" as inherently violem. backward, uncivilised and unable to transform (Hannsen 2006, 152) The same ideas can be traced back to the writings of travellew. diplomats, poets and journalists since the early nineteenth century In both cases, writers were "intrigued by and attracted to the simple, yei passionate, Balkan Romantic Other" (Hannsen 2006, 151, see alvo Todorova 1997, Goldsworthy 1998, Hammond 2002). This does mean, however, that the manner in which the wars of 1912-13 occurres should still have a "presentist" historical attraction; nor should they be o reference point for understanding contemporary events in the region, of for defining strategies and policies towards it.

The Balkan Wars have remained a significant subject in the history of the region. Therefore, they deserve a more profound investigation and above all a more analytical approach. This paper does not seek to establisti more "reliable" facts about the events on the battlefield and elsewhere, or to argue for the "objective" truth about the "real" causes of war. Instead. I am intrigued by the question, which is more relevant now than ever, of how and why these wars have become a symbolic representation of the region. There are many points at issue: for instance, the supposed continuation of legacies of the past into the present; the ways in which specific accounts of atrocities are interpreted; the ways in which these wars have become the benchmark for "Balkanisation" in the modern world; the degree to which Western observers have equated these wars with the civilisational characteristics of the region; and, last but not least, the relationship between wartime atrocities, moral indignation and the course of international policy.

There have been three main approaches to this subject: a realist approach that is focused on power relationships; an idealist or pacifist approach that is based on opposition to war; and a revisionist, humanist 
spproach that emphasises "history from below" or the daily life of indinary peoples. These three accounts will be discussed below in three woparate sections. In each case, I do not simply review the facts or the interpretations of the old Balkan Wars. I rather seek to articulate the insights of the former as they relate to the latter. The outcomes of this complex process will be analysed throughout the paper, moving from an overall reflection on how the facts about the wars are selected to a conceptual interpretation of the constitutive factors of dominant narrative and related discursive practices. Ultimately, the discussion is mtended to show the extent to which writings about these wars can rreate and represent another, unsuspected reality.

\section{In the Name of War: The Realist Account}

The first account of the Balkan Wars may be considered "realist" because of the emphasis on the power struggles and secret diplomacy between Buropean chancelleries and the Balkan states in the context of the "Eastern Question". In this account the central problem of both European and Balkan politics is power. The use of force is taken as unavoidable in a condition of anarchy where states seek to maximise their power and minimise the ability of others to jeopardise their existence. Among other things, nationalism can be used as a means of mobilising a mass army to increase the military power of the state (Posen 1993). Hence, the First Balkan War of October 1912-May 1913 was fought to force the declining Ottoman Empire to leave the region after almost 500 years, thus providing new strength to competing Balkan states.

The Balkan Wars cannot be separated from the broader context of the political, economic, social and cultural conditions arising when nationstates were created across central and eastern Europe. These conditions created a burning feeling of national resentment and a climate extremely favourable to the production of all-encompassing ideological solutions, which led the local intellectual elites to consider nationalism a viable strategy for overcoming their problems (Greenfeld 1992). As an ideology, nationalism started with German romantic resentment in reaction to the universalism underpinning French enlightenment, thus giving birth to pan-Germanism. Paradoxically, the German reactions induced a similar resentment, giving birth to pan-Slavism (Sundhaussen 
1973). Other national elites reacted not only to pan-Germanism but alin to pan-Slavism. This was the case with developing forms of Nect Hellenism and other competing, mutually exclusive Balkan narional ideologies, which from the start were aimed at discovering a glorioits ancestry. In the process widespread interest was generated in the exaltacion. of one's own national culture and history together with the "scientifie ideal of nation-building. Such movements have been institutionalised $m$ the Balkans, as we see in the case of Albania (Doja 2014), during periodi when the need was felt for a project that could specify tasks of "national importance. This would confirm that there really existed a nation, and tha in its pretensions to independent statehood the nation had a contimuif of territorial possession and an historical legality or at least cultumi legitimacy. The historical inaccuracy of the pretentions is not acknowl edged in these projects and it is ideologically stabilised by the idea of the uniform Ideal National State.

The nation-building process was inherently painful and destructim The nation had to be created first in the minds and hearts of the peoples and the state had to "liberate" and "cleanse" national territory of the polluting "others". Political violence in the Balkans was shaped by tit way in which Balkan states' elices adopted the ready-made Europein ideologies of state and nation, while using nationalism as a means in their struggle for power (Jelavich and Jelavich 1977, 216-21). Mors than anything else, mass violence and ethnic cleansing in the Balkans stemmed from underlying patterns associated with the evolution of tie modern European states becoming "national" and working with varying degrees of success to homogenise their societies. This is "the nefarious underside of Western societies since the Enlightenment and the French Revolution", and as Mark Biondich put it:

In the Balkan setting, nationalism has drawn on European models and intellectual stimuli beginning with the Enlightenment, As such, and notwithstanding attempts to typologize the phenomenon, Balkan nationalism has never been unique or original, but merely reflected European trends... In the diverse Balkans, where nations were dominated by empires, nationalism characteristically took the form of protest against empire, be it the Ottoman or Habsburg, and developed in a region of remarkable ethnolinguistic multiplicity. This became problematic insofar 
as political and national frontiers were typically incongruent. Nationalism was thus by definition a revolutionary force everywhere in Europe, not least of all in the Balkans. (Biondich 2011, 11)

After the expulsion of the Ottoman Empire, political violence continued as an expression of the struggle for power and dominance among the Balkan states. If the First Balkan War was targeted at the division of the spoils of territories once under Ottoman rule, the rush to create the "Great Nation" produced the Second Balkan War of June-July 1913 (Jelavich 1991, Glenny 1999, Hall 2000). What changed were the warring parties, but not the struggle for power. From a realist perspective, both wars were an expression of the same power game.

War in this realist logic constitutes a legitimate tool of politics and is even considered as unavoidable in the condition of anarchy. It remains questionable, however, whether the Balkan Wars were an internal byproduct of great power rivalry, or were caused by a combination of both internal and external factors. The Congress of Berlin in 1878, for instance, made decisions of lasting importance for the Balkans. As Stavrianos argues:

For the Balkan peoples, then, the Berlin Treaty meant not peace with honour but rather frustration of national aspirations and future wars. The direct and logical outcome of the Berlin settlement was the Serbian-Bulgarian war of 1885 , the Bosnian crisis of 1908, the two Balkan wars of 1912-13, and the murder of Archduke Francis Ferdinand in 1914. (Stavrianos 2000, 393, 412)

Following the realist argument, states try to maximise their power unilaterally by developing their military strength, or by creating alliances with other states to counterbalance the most powerful. Hence, the newly created states in the Balkans, competing for the supremacy of each one's "great" nation, built alliances with each other and with the great powers of the continent (Hanotaux 1914, Albrecht-Carrié 1973, Jelavich 1991). In international politics the use of alliances to gain power to counter adversaries and consolidate states' existence is considered normal. This is a multidimensional process where states use others as they are, in turn, used by the fittest in the system. It is understandable, therefore, that the new Balkan states were also used by 
the European powers and the result has not been always as expected In this context, each Balkan state was looking for association wich one at another European power (Seton-Watson 1937, 555), mainly throust, intensive secret diplomacy to which Henry Kissinger attributes a caunal role in starting wars (Kissinger 1995). Ultimately, the Balkan stames became both actors in the European balance of power as well as playen in a secondary balance of power between themselves.

The First Balkan War came as a surprise to the European chancelleries, although ultimately welcomed and hailed with enthusiasm: at least die old "Eastern Question" would be resolved. However, Arnold Toynlue argued that this was in fact a "Western Question" (Toynbee 1922), as if was in French, British and Russian interests to weaken Ottoman power and to use the Balkan states as a barrier against German and Austria Hungarian penetration into the Balkans and Asia Minor. The Europeim powers cleverly exploited the nationalist aspirations of Bulgaria, Serbin and Greece in respect of the Ottoman Balkan territories, so as to entangle them in a proxy war. Austria-Hungary, for instance, had no specind authority to intervene in the division of these territories between the Balkan states that invoked the right of conquest to compensate their enormous sacrifices. However, the proposal for an independent Albania, presented by Vienna, aimed at stripping the Montenegrins, Serbians, and Greeks of the main results of their victories. In turn, while the other European powers were already conceding the principle of an autonomous Albania to Austria-Hungary, it was obvious that this Albania would be restricted in size in order to reconcile Austrian preferences with the righos of the victorious Balkan powers. If Austria-Hungary was more or les supported in its ambitions by Germany and Italy, the Balkan states had France, Britain and Russia as their natural supporters. As Asquith, the British Prime Minister proclaimed on 9 November 1912: "The victorioun shouldn't be deprived of such an expensive victory" (quoted in: Kolev and Koulouri 2005, 98). ${ }^{1}$

The decline of Ottoman power in the late nineteenth century opened the way to the competition of European powers for control and influence in the Balkans as elsewhere. If we consider the situation from a realist perspective, this was essential from the viewpoint of preparation for the impending European war. Indeed, according to several historical accounts, from the end of the nineteenth century onward the European rivalries grew more bitter and finally exploded in 1914, with the Balkan Wars 
being only a verifying test (Bridge 1972, Crampton 1979, Rossos 1981, Jelavich 1991, Hall 2000). As Leon Trotsky wrote from the Balkan front in March 1913, these wars "have not only destroyed the old frontiers in the Balkans", they have also "lastingly disturbed the equilibrium between the capitalist states of Europe" (Trotsky 1980, 314). According to neorealist predictions (Waltz 1979), as long as the equilibrium fails to be established war has to be expected, and as Richard Hall put it:

The Balkan Wars of 1912-1913 occurred because of the determination of the Balkan states to resolve their issues of national unity in the face of the weakness of the Ottoman Empire and the opposition of the Great Powers. By 1912 the Great Powers, who had maintained peace in the Balkan Peninsula since 1878 through the mechanism of the Berlin settlement, lacked the determination to enforce it when confronted by Balkan unity. Because of this failure they would find themselves at war within two years. (Hall 2000, 21)

Such a realist account of the Balkan Wars illustrates the endemic result of anarchy, in which destruction and violence are simply a common but not deliberate - by-product of states' quest for survival. In this regard any wars, be they in the Balkans, Europe or elsewhere, are all the same regarding their causes and outcomes. Accordingly, the ethical and moral questions of war should be subordinated to the superior logic of "patria" and "national interest" as the principal raison d'être for all states in the international system. This account of war tends to lose sight of the social consequences of conflict. Worse, they are considered to be natural. To avoid the pitfall of realist accounts of war, a systematic analysis of war's social impact is necessary. That is why idealist ideas came into being and encouraged a movement in the name of peace from the mid-nineteenth century onwards. Therefore, social effects became an important part of the narratives of war.

\section{In the Name of Peace: The Idealist Account}

The period from 1856 to 1909 can be considered as the "epoch of highest repute" (Best 1980, 129) for the pacifist movement. At its core was the idea of "an unconditional rejection of all forms of warfare" (Brock and 
Socknat 1999, ix), an assumption that was based on the moral and ethical values of human society. At the heart of pacifist ideas and practice, as Brian Orend put it, was the conviction that "there are no moral grounds which can justify resorting to war. War ... is al ways wrong" (Orend 2000, 145-6). This period also witnessed a number of conventions and declarations that attempted to codify the reason for states to engage in wat ( jus ad bellum), to impose limits of conduct in wartime ( jus in bello), and 6. create institutions to manage and arbitrate the disputes among states, like the Court of Arbitration established in Hague in 1899 (Schindler and Toman 2004, 22-34). Even though "pacifism and just war ideas am incommensurable (the former banning war and the latter justifyin limited war)", they "share a common starting point: a moral presumption against the use of force" (Cooper 1991, 16).

In principle, it can be argued that the pacific movement must have encouraged a social, legal and politically idealist account of war, entirely different in focus and purpose from the predominant pessimist amol cynical realist approach. In a realist account the relationship between wat and civilians as a subject of war is either ignored or considered w collateral damage, which must be minimised but which is unavoidable By contrast, in the new approach, the centrality of civilians must bi shown in the narrative of war and strong media coverage must br carefully given to this narrative, which is expected to result in cle abolition or the control of war.

The international survey of the Carnegie Endowment for International Peace in 1913 and the Report published in 1914 on the Balkan Wars provides an excellent example of writing about war from i moral and legal idealist point of view. Contrary to some interpretation. the aim of the Carnegie Report was not the study of the causes of the Balkan Wars, which remains the primacy of a realist perspective. Rather. the overall purpose of the Carnegie Report owed much more to the icteis of the endowment's founder, Andrew Carnegie. His aspiration was abovi all to "hasten the abolition of international war, the foulest blot upon out civilization" (Finch 1944, 214). Nicholas Murray Butler, the director of Endowment at that time, perfectly in compliance with Carnegie's own ambitions, clearly stated the purpose of the Report:

to inform public opinion and to make plain just what is or may be involved in an international war carried on under modern 
conditions. If the minds of men can be turned even for a short time away from passion, from race antagonism and from national aggrandizement to a contemplation of the individual and national losses due to war and to the shocking horrors which modern warfare entails, a step and by no means a short one, will have been taken toward the substitution of justice for force in the settlement of international differences. It was with this motive and for this purpose that the Division of Intercourse and Education of the Carnegie Endowment for International Peace constituted in July, 1913, an International Commission of Inquiry to study the recent Balkan wars. (Carnegie 1914, Preface)

Founded in 1910 the Carnegie Endowment was a non-governmental organisation zealously engaged in the pacifist movement. Its objectives were the promotion of international public awareness, by providing cvidence and information about the effects of war on civilian population, and support of international laws and organisations for the arbitration and peaceful settlement of disputes among states. The best way to support these goals was to give compelling examples. Indeed, it can be irgued that the purpose of Carnegie Endowment was not to point to the Balkans as an exceptional case, but to find a specific case in the Balkan Wars in order to expose the wrongdoings of secree diplomacy and power games leading to wars. This would induce sufficient indignation either to prompt humanitarian intervention or to encourage the creation of international legislation on the treatment of civilians in war and on the limitation of the political and socioeconomic implications of war.

Given the connection of the Carnegie Endowment to the pacifist movement, it is not surprising that the Carnegie Commission operated us an effective and active advocate of the idealist means used by pacifist movements to either abolish or control war. There was, for instance, a high degree of consensus among the members of the Commission ubout the facts to be collected and the ideas to be disseminated. The membership of the Carnegie Commission represented a network of professionals with recognised expertise in the legal aspects of war and in the Balkans, seriously involved in the activism of the pacific movement. ${ }^{2}$ The Report was intended to act as a means of teaching and helping states ro better identify their own interest, in favour of moral norms rather than political violence and war. 
The empirical evidence published in the Report of 1914 was based on fieldwork observations, reports of torture from civilian witnesses and victims, and the inspection of destroyed villages, religious sites and mass graves. This was a new method of inquiry in international relations, apparently influenced by the ethnographic methods used in sociology and anthropology. However, accounts of violence in war were converted into a normative account of war, reported as instances of violations of laws and customs of war. ${ }^{3}$ This clearly shows the idealist way in which the story of the 1912-13 Balkan Wars was put in writing and offered to the public in order to further the pacifist agenda.

Pacifist activists saw that making public the tragic story of war was an important means of persuasion. The most obvious way to advance this approach was through the exposure of war to close scrutiny by civilian reporters, A public debate was expected to replace secret diplomacy and pressurise governments to give up their engagement in wars. The expectation was to move from a world of the "initiated" to a "pedagogy of public opinion", which is considered to be crucial for the pacification of international society (Dzovinar 2008, 14). The mechanism at work seems to be the ancient Greek political model of Polis, where the exercise of power is a property of the body of citizens rather than of a small oligarchy (Vernant 1981, 42-5; 97-9). The community of citizens would be empowered to control war, while the best way to achieve this purpose was to make public the necessary information in a welldocumented and convincing form. Following this logic, the collection of this "evidence" was the main objective of the Carnegie Endowment's International Commission of Inquiry.

Abundant evidence of the "atrocities" in the First and Second Balkan Wars was reported by the press (Sipcanov 1983). The Carnegie Report itself was released in both French and English versions. A press release was sent in May 1914 to no less than 1,250 newspapers around the world, advertising the publication of the Report in print and copies of it: were sent upon request. The main purpose of this press release was not to miss the "psychological moment, both here [in the Balkans] and abroad" (quoted in Akhund 2012). ${ }^{4}$ However, by publicising atrocities of the Balkan Wars "as a lasting testimony to the kind of hell-on-earth that only humans can create", the Report added nothing to war reporting since the mid-nineteenth century (Moorcraft and Taylor 2008, 4). This kind of 
reporting was exemplified by the Times correspondent William Howard Russell sending first-hand dispatches from the front line of the Crimean War (1853-6), which engaged public sensitivities and triggered the fall of Lord Aberdeen's government. This clearly showed how the political establishment might become aware that provoking public anger and dissent could have unintended consequences and may, in turn, impose changes to state policies.

The Carnegie Report, like other war reports, arguably promoted a specific reading of the painful "truth" resulting from wars - a "truth" about barbarism and the reign of violence. The Report appeared in several countries as an exceptional document of the time providing a new definition for international affairs and contributing to the foundations of modern international cooperation. As part of an organised strategy to document the atrocities and outrages of war, which was designed to persuade a sceptical international public about the irrationality of war and to show political responsibility for the prolonged hostilities in the Balkans, the Report succeeded in promoting the peace movement. Arguably, the Report encouraged efforts for codifying international behaviour and especially enabled international humanitarian law for settling international disputes through arbitration and conciliation. Hence, the ideas advanced in the Report played a crucial role in creating the shared understanding toward a practice of war control. These ideas were finally embodied in the Charter of the League of Nations and the Kellogg-Briand Pact outlawing war, both signed in Paris in 1920 and 1928 respectively.

Nevertheless, the Carnegie account of the Balkan Wars cannot be separated from a broader historical and political context in which the communist movement and its activism against war emerged as another kind of pacifism, which favoured but one war, the proletarian revolution, as the only means to liberate the oppressed peoples and human society as a whole from war (Cooper 1991, 28). In this context, many socialist groups and political movements within the Balkans, even though often alienated and overlooked, also strongly opposed the official policies of the Balkan governments leading to war, along similar lines to the activism of European pacifist movements. Sometimes their pacifism and antimilitarism originated from different ideological motivations, not necessarily related to a nature of war as a type of governmental coercion of the working class for the benefit of capitalist elites. 
On the eve of the outbreak of war, the Social Democrats were one of the most well-organised political groups that mobilised activity against the war in most of the Balkan countries (Kolev and Koulouri 2005, 45-7). The Congresses of the Serbian Social Democratic Party and the Bulgarian Social Democratic Workers Party both took place in 1912 under the banner of the struggle against war and the call for a peaceful settlement of national problems. In September of the same year, they organised rallies and mass meetings against the war in Belgrade, Sofia, Thessaloniki, and Bucharest that showed the solidarity between all Balkan socialists (Damianova 1989, 69). During the years of war, sections of the socialist parties in the Balkans worked as a joint political force for peace and opposed the war policies and the political violence of their governments (Stavrianos 1964, 182-90, Haupt 1972, 56-82). They even went so far as to propose a joint solution to the separate national problems by peaceful and democratic means. They opted for the idea of a Balkan federation or alliance presented as the general solution to the political and social problems of south-east European countries.

The media of the time covered the idea of a Balkan Alliance supported by the meetings of Serbian and Bulgarian youth, cultural workers and intellectuals. According to Ivan Vazov, a Bulgarian poet of the time:

The Balkan Alliance is a word which I wish from all my heart to take on human form (body and blood) and become a reality as soon as possible. And why hasn't it become a reality yet? There are many reasons for that: mistakes from our histories (both Serbian and Bulgarian), our past, ancient and recent; lack of mature political thought among those who direct the fate of our two nations, weakness for mutual conflicts and rivalry, typical only of the Slavs. As one can see, there are many obstacles for carrying out this idea. We should arm ourselves with courage for mutual concessions; we should have the courage to forget all selfish national concerns and to think only of one thing: that both the Bulgarian and the Serbian people will be free, mighty and great only in a fraternal march forward in firm political alliance ${ }^{5}$.

Likewise, the Serbian Social Democratic Party deputy Lapcevic delivered a speech to the Serb National Assembly on 7 October 1912 defending 
the idea of peace because "the war between the Balkan peoples ... would be bloody and terrible for us, Balkan peoples, because it would degrade and ruin us". 6

Calling attention to the historical contextualisation of the idealist accounts of the Balkan Wars does not mean, however, we must offer comfort to a realist approach. It simply means that idealism did not necessarily prove to be the best way to deal with war in international relations. The extent to which the Carnegie Report might have influenced the dynamics of Balkan wars did not escape even Andrew Carnegie, who seems himself to not have entirely approved the outcome of the Commission inquiries, commenting at that time that the Report could exacerbate antagonisms (Akhund 2012, 6). Baron d'Estournelles de Constant, the President of the Carnegie Commission, also sought to defend his collective against the accusations of pacifism of which he was clearly aware:

Let us repeat, for the benefit of those who accuse us of "bleating for peace at any price", what we always maintained: war rather than slavery, arbitration rather than war, conciliation rather than arbitration. (Carnegie 1914, 1)

It is certainly not enough to assume that the greater the legitimacy and morality of ideas, the greater is the likelihood that the states will exert their power on behalf of the values and practices promoted by these ideas and will establish the corresponding international institutions and legal regimes. In international relations, ideas are only turned into policies when they best fit the interests of policymakers in reaction to a combination of constraints engendered by domestic politics and the power configuration of the international system. Neither the pacifist ideas in favour of prohibition or control of war nor the revolutionary ideas against war are a guarantee of the emergence of international peace order. In an anarchical world, one idea is not necessarily shared by all political actors. In addition, the competing idealist alternatives of pacifism, all claim to provide sound arguments regarding what is needed to be done for an order of peace in international relations. However, in one case or the other the burden still remains once again with the political decision-makers who have to take on the ideology that best suits their power interests. 
Finally, any underlying ideas about a world without war may be deemed rational. Yet, putting them into practice is likely to prove very difficult and even impossible. The relationship between ideas and reality, especially the interdependence of facts, social exigencies, actors' interests and a new international order is much more complicated than the simple distinction between the transformational power of ideas and the real transformation of the international order. More than anything else, the outbreak of both World Wars I and II can be seen as the failure of the pacifist movements for the codification and the abolition of war. Beyond the activism and faith of both pacifism and communism, the idealistic account if contrasted with a humanist narrative of war may still help us to understand the negative symbolic representation that is constructed by default from this specific exposition of the Balkan Wars. This will be discussed in the final parc of this paper.

\section{In the Name of People: A Revisionist Approach}

A revision of both realist and idealist accounts can lead to a "history from below", thereby providing an alternacive narrative of the Balkan Wars. At the beginning of the last century, contrary to the atrocities and hatreds that feature so prominently in both realist and idealist accounts of war, the humanitarianism of ordinary people in Balkan societies was not reported extensively in the West. It was also largely absent from the many publications dealing with the conflicts accompanying the dissolution of Yugoslavia. However, different observations suggest that people's life and their interaction in a given social context (e.g. war, cooperation) relate to their collective representations that can be seen, following Wendt's logic (1994, 385-90), as a reliable source in the evaluation of perceptions, shared understandings and expectations. They can help better understand the course of common action that can be different from state behaviour. In addition, this shows ordinary groups to be real rather than ideological entities, and this distinction can have an impact on the narrative of war.

In this view, it is particularly important that some recent publications have brought back the experience of war as discussed by soldiers and ordinary people of different nationalities in handwritten letters, or exposed in photographs and drawings, which show both the commonality of suffering and feelings of camaraderie among formally recognised enemies. 
In addition, these publications have documented the role of woman in wartime from both the perspective of idealised woman (as mother or heroine) and that of actual heroine at or behind the front lines (as nurses, mothers and wives) (Kolev and Koulouri 2005, 68-73, Biondich 2011, Dimitrova 2013). These images and accounts consciously and unconsciously challenge the stereotypes of enduring enmities, as well as the preconceived ideas of the relationship between human behaviour and ethnicity. They counter the association of violence and destruction with cultural, religious and ethnic stereotypes, and suggest that human beings appreciate human values and feel compassion for those sharing the same suffering, regardless of the prejudices that may have depicted the other as culturally and ethnically different. In fact, after desperate fighting and destruction, many of the survivors managed to overcome hatred and distrust. As a war correspondent observed, "often the enemies of yesterday were shaking hands. Short episodes like these were repeated frequently" (Berri 1913, 252). After all, Balkan peoples must have been peacefully coexisting wich each other for long periods in the past. Even though the published evidence is still limited, it is difficult to conclude that the culture of violence is what most characterises the peoples of the Balkan.

By contrast, as I have already indicated in the two previous sections, the Balkan Wars are presented exclusively in terms of atrocities, making it difficult to think outside of this particular conceptual universe. The effort to avoid the ambiguity between aims and means was stated explicitly by the investigators of the Carnegie Commission. However, exposing the wars' brutal horrors and ignoring the power dynamics at European and Balkan levels, let alone the presence of humanitarianism in practice, is highly problematic. This amounts to inverting the usual order of objective investigation, in which description becomes prescription that precedes explanation. This is especially troublesome as it makes it notoriously difficult to distinguish between facts and the propaganda of nationalist, militarist, pacifist, or communist ideology. As a result, there is a considerable risk of investigators being forever stuck at the stage of identifying the "other" based on pre-conceived beliefs and perceptions that become oddly prescriptive.

On the one hand, prescriptive representations help to shape the image and to create the reputation of discussed subject. This can be well illustrated by both realist and idealist representations of wars in which 
atrocities and hatred are, therefore, formulated according to a binary discourse on civilisations that juxtapose the barbarism and backwardness of Balkan peoples and nations against a civilised Europe. This is the case with the Carnegie Report in which Balkan peoples were depicted as "not far from us, [they] were then, and are still, unlike Europe, more widely separated from Europe than Europe from America; no one knew anything of them, no one said anything about them" (Carnegie 1914, 3). The complex meaning of the Balkan Wars is assumed to only be grasped in the context of a "typification" of differences between Europe and the Balkan "other". On the other hand, recurrent exposition and highlight of a particular war image instead of another might consciously or unconsciously have reinforced the prejudices towards the Balkans. Uncivilised temperament and behaviour appears as if it is inherently embedded in the social identity of the Balkan peoples. This is an essentialist approach, which assumes a tendency to autocratic and corrupted societal relations in the region, and questions its ability to embrace modernity and to achieve development and prosperity for its constituents.

The construction of all war narratives is, of course, profoundly political, favouring certain ideas and judgements over others. What is more important is that such narratives can by no means be reduced to restatements of simple objective archival facts. As Nietzsche warned, "objectivity" is not a "contemplation [Anschaunng] without interest" (Nietzsche [1887] 2007, [12]87). The main problem with the accounts of the Balkan Wars is not about the objectivity and quantification of facts. Instead, the main problem rests upon the interpretation of facts and "truths". As Edward Hallett Carr put it, "the belief in a hard core of historical facts existing objectively and independently of the interpretation of the historian is a preposterous fallacy, but one which is very hard to eradicate" (Carr 1961, 12). Accordingly, the way in which the facts of the Balkan Wars are interpreted and offered to the public may become an excellent test case of competing accounts of war and peace.

Wherever and whenever historical facts are written, specific interests are always being served. The importance of facts, events, personalities and practices in history gain meaning and are (re)interpreted in the context of particular political interests. The way that the facts of the Balkan Wars are interpreted helps us to understand how this might have strengthened the "Balkanist" discourse. In this context as in others, the role of ideas and 
discourse in the construction and reconstruction of social action must first be clarified, Competing political interests and cultural values both in the Balkans and in Europe must be seriously taken into consideration, if we aim to go beyond explanations based on rationalist interests, pathdependent history, and cultural framing preferences.

What seems to have helped the creation and revival of the stereotypes and prejudices about the Balkans is the fact that "facts" become a source of trouble due to the flux of ideas at work among Western scholars and politicians who dominate "virtually all historical references in the media, including the highbrow press" (Banac 1992, 143). Unfortunately, even though not always explicitly stated, up to now Western scholarship and politics merely tell us how the world should imagine and accordingly treat the Balkans. Emanating ideas and beliefs from this discourse serve as causal patterns that guide the selection of means to achieve some ends, and ultimately define friends and foes and accordingly the respective attitudes and actions. In principle, the prejudice seems to have been successful in constructing the distorted essential identity of the Balkans in a way that has remained unchanged for any time in spite of substantial changes. In practice, this is what has induced uncompromising, inflexible, constant and causal beliefs that seem to guide political actions towards the Balkans, as if past events may still constrain the political behaviour of national and international actors in current times.

Consequently, the barbarism in the 1912-13 Balkan Wars has been overemphasised again by some Balkan commentators in relation to later conflicts in the region. The casual reader of the international press over the past decades has been left in little doubt that the wars in former Yugoslavia were endemic, perperual and brutal (Kaplan 1993, Cohen 1993, Glenny 1996, Gallagher 2007, Hislope 2007). The argument, if one can call it that, has been advanced most prominently by former US Secretary of State Henry Kissinger in a Washington Post editorial that the US Senate ordered reprinted in the Congressional Record of 23 February $1999 .^{7}$ Balkan peoples, we are told, have no experience of and essentially no belief in Western concepts:

Ethnic conflict has been endemic in the Balkans for centuries. Waves of conquests have congealed divisions between ethnic groups and religions, between the Eastern Orthodox and Catholic faiths; between Christianity and Islam; between the heirs of the 
Austrian and Ottoman empires. These conflicts have been fought with unparalleled ferocity because none of the populations has any experience with - and essentially no belief in - Wescern concepts of toleration. Majority rule and compromise that underlie most of the proposals for a "solution" never have found an echo in the Balkans. (Kissinger 1999)

Again, the division of the Balkans from the European West is articulated to help constitute a space of moral superiority for the West. But such a way of writing and talking about the Balkans seems to yield to a reality that reflects European hypochondria rather than a sound concern about what was happening there before and after the Balkan Wars.

Contrary to what we are taught to believe, there is not the historical past, neither the enumeration of the cultural traits nor the cultural inventory of collective memories that shape and essentialise the identity of the "backward" Balkans. This is rather a function of the continuous maintenance of an imaginary social boundary defined by a long sociocultural interaction with the "civilised" Europe. In this way, as we know from a transactional perspective (Barth 1969), a careful examination of the social organisation of the established boundaries between the "backward" Balkans and the "civilised" Europe, clearly shows they are the implication or the result rather than the signifier of both Balkan and European identities. They actually derive from a deliberate process of negotiations to establish structures "comparable to potential governance structures" that define the "sets of acceptable contracting partners" (Somer 2001, 146). By contrast, in the case of both Europe and the Balkans, the quest of a cultural inventory of collective memories seems to have inspired and encouraged the need to develop an "ethno-cultural" approach, as shown specifically in the case of Albania (Doja 2014), which must emphasise the essential and immutable character of one's own people's culture, traditions, language, religion, myths, history, and so on. Often these past collective memories are used and misused in favour of given interests in the context of ideologies aimed at projecting identity boundary and hegemony by glorifying the past as a means of gaining ascendency and legitimacy in the present.

The evidence of humanitarianism during the Balkan Wars may not currently be sufficient to challenge the constructed image of the Balkans. Yet, it is noteworthy that scholars from the region are working to reveal 
such evidence, and some of it has already been published in Western academic presses (Banac 1992, Todorova 1997, Goldsworthy 1998, Hatzopoulos 2003, Kolev and Koulouri 2005, Michail 2012), which may successfully challenge the dominant constructed image of the Balkans.

\section{Conclusion}

The pervasive essentialising discourses that surround the Balkan Wars of 1912-13 appear unusual and difficult to grasp, if one schematically employs traditional categories developed in both scholarship and politics when dealing with this question. In turn, an analysis of three separate accounts, distinguished along the lines of realist, idealist and revisionist approaches, linked to a careful examination of their historical contextualisation in ideological perspective, produces a more sophisticated understanding. While analysing the history and the politics of the Balkan Wars the aim of this paper was to frame the argument in such a way as to focus on a critical reassessment of different accounts and move away from the close association of Balkan wars with the essentialisation of the Balkans. Against the discursive practice of accounts that might have created a distorted perception of the Balkans and that may have been used as a justification for policies of neglect or disdain towards the pressing problems of the region, I argue instead for considering the Balkans as an integral part of European history and politics.

In methodological terms, I engaged with a comparative analysis of ideas rather than with a search for a positive proof. I adopted a critical approach to conceptions of history and politics by focusing on political processes and power relations that define events and their place in social relations. The alternative historical evidence from the Balkan Wars is provided to assess new insights to understanding the politics of history. The aim of this paper was not to write the history of this wars, but instead examine in what way the representations and the implications of the Balkan Wars might have defined the European imagination of the Balkans. Eventually, this approach might not be exhaustive and certainly a number of questions remain open. However, if this paper has managed to provoke at the very least a non-stereotyped discussion throughout a set of reflections on what essentialising concepts and representations can do, it will hopefully constitute an encouragement for further, deeper enquiries in this direction. 


\section{Notes}

1. André Chéradame, L'lllustration, no, 3650, 8 February 1913, p. 115.

2. The commission was headed by Paul-Henri d'Estournelles de Constant, a French senator, winner of the 1909 Nobel Prize for Peace, a member of the Permanent Court of Arbitration from 1900, and French representative at both Hague Peace Conferences of 1898 and 1907 (Barcélo 1995). He knew the region very well as he had served as a diplomat from 1876 to 1882 in Montenegro and the Ottoman Empire (Jolly 1960-77). The members of the commission were also jurises involved in the pacifist movement and experts of the region. Justin Godart was a French lawyer and senator known for his pacifist engagement and as a specialist of Armenian and Balkan issues. Joseph Redlich was an Austrian politician and Professor of Public Law at the University of Vienna. Walther Schücking was a German Professor of Law at the University of Marburg, known as a fervent defender of The Hague Peace Conferences. Francis W. Hirst was Editor of the Economist from 1907 to 1916 and an activist of the international conciliation movement in London having published even a book on the law of war (Hirst 1906). Henry Noel Brailsford was a British journalist, correspondent of the Manchester Guardian (Leventhal 1985, pp. 92-112) and author of a well-known book on the Macedonian question (Brailsford 1906). Paul Milioukov was a Russian historian, politician and diplomat serving for some time in Bulgaria Samuel T. Dutton was a Professor at Columbia University and represented Carnegie Endowment at the International Commission.

3. By 1907, instances of violations of laws and customs of war had been codified in the Hague Regulations and were subject to legal proceedings referring to Articles 46-56 (Merryman and Elsen 2002, p. 28).

4. Carnegie Endowment for International Peace, "Prudhommeaux to Haskell", 12 May 1914, no. 202 (box 522), and "Butler to d'Estournelles de Constant" 12 December 1913, no. 201 (box 521), p. 10.

5. Balkanski rat u slici i recvi, 6 (24 February/9 March 1913), quoted in Kolev and Koulouri 2005, p. 43.

6. Lapcevic, Rat i sppska socijalna demokratija, pp. 61-6, quored in Kolev and Koulouri 2005, p. 46.

7. Congressional Record, vol. 145 , no. 28, p. S1762-S1763.

\section{References}

Akhund, Nadine, "The Two Carnegie Reports: From the Balkan Expedition of 1913 to the Albanian Trip of 1921", Balkanologie, 14:1-2 (2012).

Albrechr-Carrié, René, A Diplomatic History of Europe since the Congress of Vienna, revised edn (New York, 1973).

Banac, Ivo, "The Fearful Asymmetry of War: The Causes and Consequences of Yugoslavia's Demise", Daddalus: Journal of the American Academy of Arts and Sciences, 121:2 (1992), pp. 142-58. 
Barcélo, Laurent, Paul d'Estournelles de Constant, prix Nobel 1909. L'expression d'une idée européenne (Paris, 1995).

Barth, Fredrik, "Introduction", in Etbnic Groups and Bonndaries: The Social Organization of Culture Difference (Boston, MA, 1969).

Berri, Gino, L'Assedio di Soutari. Sei mesi dentro la citta accerchiata (Tho Siege of Scutari. Six montbs inside the surrounded toun) (Milano, 1913).

Best, Geoffrey, Humanity in Warfare: The Modem History of the International Law of Armed Conflicts (London, 1980).

Biondich, Mark, The Balkans: Revolution, War, and Political Violenee Since 1878 (Oxford, 2011).

Brailsford, Henry Noel, Macedonia: Its Races and Their Future (London, 1906).

Bridge, Francis Roy, From Sadowa to Sarajevo: The Forign Policy of Austria-Hungary, 1866-1914 (London, 1972).

Brock, Peter, and Thomas Paul Socknat (eds), Challenge to Mars: Essays on Pacifism from 1918 to 1945 (Toronto, 1999).

Carnegie, Report of the International Commission to Inquire into the Causes and Conduct of the Balkan Wars (Washingeon, DC, 1914).

Carr, Edward Hallett, What is History? (London, 1961).

Cohen, Lenard J., Broken Bonds: The Disintegration of Yugoslavia (Boulder, 1993).

Cooper, Sandi E., Palriotic Pacifism: Waging War on War in Europe, 1815-1914 (New York, 1991).

Crampton, Richard J., The Hollow Detente: Anglo-German Relations in the Balkans, 1911-1914 (Atlantic Highlands, NJ, 1979).

Damianova, Jivka, "La Fédération contre l'alliance militaire: les socialistes balkaniques et les guerres balkaniques 1912-1913", Le Mowement Social, 147 (1989), pp. 69-85.

Dimitrova, Snezhana, "The Balkan War Evidences - Another War Heritage: A Study of Soldiers' Notebooks, Letters and Drawings", Paper read at The Balkan Wars 1912-13 International Conference, Regensburg Institut für Ostund Südosteuropaforschung and Tirana Institute for Southeast European Studies, Tirana, 11-12 June 2013.

Doja, Albert, "From the Native Point of View: Folkloric Archaism in Albanian Studies", History of the Human Sciences, 27:4 (2014).

Dzovinar, Kévonian, "L'enquête, le délit, la preuve: les 'atrocités' balkaniques de 1912-1913 à l'épreuve du droit de la guerre", Le Mowvement Social, 222:1 (2008), pp. 13-40.

Hinch, George A., "James Brown Scott, 1866-1943", American Journal of International Law, 38:183 (1944), pp. 188-215.

Giallagher, Tom, The Balkans in the New Millennium: In the Shadow of War and Peace (New Jersey, 2007).

Gilenny, Misha, The Fall of Yugoslavia: The Third Balkan War (London, 1996).

The Balkans: Nationalism, War and Greats Powers $1804-1999$ (London, 1999).

Goldsworthy, Vesna, Inventing Ruritania: The Imperialism of the Imagination (New Haven, 1998).

Greenfeld, Liah, Nationalism: Five Roads to Modernity (Cambridge, MA, 1992).

Hall, Richard C., The Balkan Wars 1912-1913: Prelude to the First World War (London, 2000).

I lammond, Andrew, The Debated Lands: British Travel Writing and the Construction of The Balkans (Warwick, 2002). 
Hannsen, Lene, Secturity as Practice: Discourse Analysis and the Bosnian War (London. 2006).

Hanotaux, Gabriele, La guerre des Balkans et l'Europe (1912 - 1913), 2nd edn (Paris, 1914).

Hatzopoulos, Pavlos, "All That is, is Nationalist: W'estern Imaginings of the Balkam since the Yugoslav Wars", Journal of Southern Europe \& the Balkans, 5:1 (2003) pp. $25-38$.

Haupt, Georges, Socialism and the Great War: The Collapse of the Second International (Oxford, 1972).

Hirst, Erencis W., The Arbiter in Conncil (London, 1906).

Hislope, Robert, "From Expressive to Actionable Hatred: Ethnic Division and Riot in Macedonia", in Jenkins J. Craig and Esther E. Gottlieb (eds), Identity Conftion. Can Violence Be Regulated? (New Brunswick, NJ, 2007), pp. 149-66.

Jelavich, Barbara, Russia's Balkan Entanglements, 1806-1914 (Cambridge, 1991).

Jelavich, Charles, and Barbara Jelavich, The Establishment of the Balkan National Stater. 1804-1920, vol, 8: A History of East Central Europe (Seattle, 1977).

Jolly, Jean, Dictionnaire des parlementaires français: Notices biographiques sur les ministres. dếputés et sénateurs français de 1889 à 1940, 8 vols (Paris, 1960-77).

Kaplan, Robert D., Balkan Ghosts: A Journey Throngh History (New York, 1993).

Kennan, George F., "Introduction", in The Other Balkan Wars: A 1913 Carnegie Endowment Inquiry in Retraspect with a New Introduction and Reflections on the Present Conflict (Washington, DC, 1993).

Kissinger, Henry, Diplomacy (New York, 1995).

"No US Ground Forces for Kosovo: Leadership Doesn't Mean That We Musi Do Everything Ourselves", Wasbington Post, 22 February 1999.

Kolev, Valery, and Christina Koulouri, The Balkan Wars (Thessaloniki, 2005).

Leventhal, Fred M., The Last Dissenter: H,N. Brailsford and His World (Oxford, 1985)

Merryman, John Henry, and Albert Edward Elsen, Law; Ethics. And The Visual Art, 4th edn (New York, 2002).

Michail, Eugene, "Western Attitudes to War in the Balkans and the Shiftiny Meanings of Violence, 1912-91", Journal of Contemporary History, 47:2 (2012), pp. 219-39.

Moorcraft, Paul, and Philip M. Taylor, Shooting the Messenger: The Politics of Way Reporting (Washington, DC, 2008).

Nieczsche, Friedrich, On the Genealogy of Morality: Essay III, trans. by Carol Diethe, ed. by Keith Ansell-Pearson: Cambridge Texts in the History of Political Though (Cambridge, 2007 [1887]).

Orend, Brian, War and International Justice: A Kantian Perspective (Waterloo, ON, 2000)

Posen, Barry, "Nationalism, the Mass Army, and Military Power", International Security $18: 2$, pp. $80-124$.

Rossos, Andiew, Russia and the Balkans: Inter-Balkan Rivalries and Russian Foreign Policy, 1908 - 1914 (Toronto, 1981).

Schindler, Diecrich, and Jiri Toman (eds), The Laws of Armed Comflicts: A Collection of Conventions, Resolutions, and Other Documents, 4 th edn (Boston, 2004).

Seton-Watson, R.W., "The Little and Balkan Entente", The Slavonic and Eall European Review, 15:45 (1937), pp. 553-76. doi: 10.2307/4203275.

Simić, Predrag, "Balkans and Balkanisation: Western Perceptions of the Balkans in the Carnegie Commission's Reports on the Balkan Wars from 1914 to 1996", Perceptions, 18:2 (2013), pp. 113-34. 
Sipcanov, Ivan, Les correspondants de guerre pendant les guerres balkaniques de 1912-1913 (Sofia, 1983).

Somer, Murat, "Cascades of Ethnic Polarization: Lessons from Yugoslavia", Amals of the American Academy of Political and Social Science, 573:1 (2001), pp. 127-51.

Sravrianos, Leften Stavros, Balkan Federation: A History of the Movement towards Balkan Unity in Modern Times (Hamden, 1964).

The Balkans since 1453 (London, 2000).

bundhaussen, Holm, Der Einfluss der Herderschen Ideen auf die Nationsbildung bei den Vo.lkern der Habshurger Monarcbie (München, 1973).

Todorova, Maria, Inagining the Balkans (New York, 1997).

Toynbee, Arnold J., The Western Question in Greece and Turkey (London, 1922).

Trotsky, Leon, The Balkan Wars 1912-13 (New York, 1980).

Vernant, Jean-Pierre, Les origines de la pensée grecque (Paris, 1981).

Waltz, Kenneth J., Theory of International Politics (New York, 1979).

Wendt, Alexander, "Collective Identity Formation and the International State", American Political Science Review, 88:2 (1994), pp. 384-96. 